doi: https://doi.org/10.15407/microbiolj83.04.098

\title{
A REVIEW OF NOSOCOMIAL INFECTIONS: SOURCE AND PREVENTION
}

\author{
D.B. Phule, A.V. Manwar \\ Department of Microbiology, \\ Dnyanopasak College of Arts, Commerce, Science, and \\ Technology, College, Parbhani, (India) \\ e-mail: research.vlsrc@gmail.com
}

\begin{abstract}
Nosocomial infections are a severe public health concern around the world, particularly in developing nations where infection control is difficult owing to financial constraints. Despite the significant drop in infectious disease due to advances in medical technology and medicine, it is well acknowledged that nosocomial infection has been one of the key impediments to better health conditions. The spread of bacterial species associated with number of medical devices for example commonly used stethoscope is one of the sources of infection. The presence of coagulase negative Staphylococcus species, Enterococci species, Escherichia coli, Klebsiella species and Acinetobacter species found to be common on stethoscope. The indiscriminate use of antibiotics without any regulation and proper screening certainly making many antibiotics non-functional to control their targeted pathogens. The hospital acquired pathogens mainly showcase increased incidences of antibiotic resistance. The purpose of this study is to examine epidemiologic characteristics of nosocomial infection and to find out effectives measures for their preventing.
\end{abstract}

Keywords: Nosocomial infections, microbial pathogens, prevention and transmission.

The incidences of nosocomial infection or healthcare associated infections mainly occur in patients undergoing medical care that are evidenced worldwide. The infections of such kind not only occur at a local area of country since it remains widespread. As per status of countries, incidences are recorded with higher percentage $(10 \%)$ in underdeveloped countries as compared to developed one (7\%) [1]. The real effect of hospital acquired nosocomial pathogens leads to prolonged hospital stay, disability, and increased economic burden. Taking a serious note of nosocomial infection, WHO carried out research studies to report $15 \%$ of all hospitalized patients suffer from these infections. The major sources of infection in hospitals settings are the environment, health care staff, and admitted patients itself [2]. The spread of nosocomial infection also linked with commonly used catheters and ventilators in recent health care services. The most affected patients are from the intensive care units (ICUs), burn units, neonates and those undergoing organ transplants. The majority of cases are recorded among those admitted in ICUs as high as $51 \%$ making it the serious concern $[3,4]$.
As per today's scenario rise in nosocomial cases related with increased hospital stay, long term disability, socio-economic disturbances, antimicrobial resistance, and mortality rate. The fact sheet of nosocomial infection is logarithmic in nature - since we have limited information about its presence, control and planning for its management. For example, once the patient is admitted in hospital for the treatment of other disease, they receive respiratory infection and occurrence is tough to get detected mainly in primary care facilities [5]. Hence the presence of nosocomial infection only noticed when the infection becomes epidemic, and unfortunately not a single institute or a country claim to have resolved this endemic problem [6]. By considering the threat of increasing nosocomial infection, it is important to know the sources of origin in hospital settings, so that future controlling methodology could be designed to cope up with the situation.

Health care-associated infections (HCAIs) are those infections that patients acquire while receiving health care treatment at hospital [7]. The term HCAIs initially referred to those infections linked with admission to an acute-care hospital 
(earlier called nosocomial infections) [8]. The term now includes infections developed in various settings where patients obtain health care such as, long-term care, family medicine clinics, home care, and ambulatory care. HCAIs are infections that first appear 48 hours or more after hospitalization or within 30 days after having received health care [9]. The US Center for Disease Control and Prevention identifies that nearly 1.7 million hospitalized patients annually acquire HCAIs while being treated for other health issues and that more than 98,000 of these patients (one in 17) die due to HCAIs [10].

\section{Types of nosocomial infections}

The most frequent types of nosocomial infection include central line associated bloodstream infections, catheter-associated urinary tract infections, surgical site infections and ventilatorassociated pneumonia.

Central line-associated bloodstream infections (CLABSI)

As per one study $-5 \%$ of hospitalized patients in US showcased acquired infections. Among them, central line-associated bloodstream infection (CLABSI) reported more deadly since its mortality rate recorded between $12 \%$ and $25 \%$ [11]. The application of catheters through central line that is involved in supplying fluid and medicines if prolonged, it leads to serious blood stream infections that result in compromised health and increased care cost [12].

CLABSI is defined as a laboratory-confirmed bloodstream infection not related to an infection at another site that develops within 48 hours of central line placement [13]. CLABSIs are deadly nosocomial infections with the death incidence rate of $12-25 \%$ [14]. Catheters are placed in central line to provide fluid and medicines but prolonged use can cause serious bloodstream infections resulting in compromised health and increase in care cost [15]. Although there is a decrease of $46 \%$ in CLABSI from 2008 to 2013 in US hospitals yet an estimated 30,100 CLABSI still occur in ICU and acute facilities wards in US. Each year CLABSIs substantially increase morbidity, mortality, and health care costs, and great attention has been paid to addressing these. The most common causative pathogens were Gram-negative (39.2 \%), Gram-positive (33.2\%), and Candida spp. microorganisms $(27.6 \%)[14,16]$.

\section{Catheter associated urinary tract infections (CAUTI)}

The nosocomial urinary tract infection mainly reported with patients hospitalized and those associated with catheterization. The infection also been evidenced with closed catheter system. Even after taking intensive care - bacteriuria generally develops and leads to nosocomial infection for many instances [17]. As per one report, in acute care hospitals, UTI accounts for $12 \%$ of reported infections [14]. As catheter associated urinary tract infections (CAUTI) resultant by the endogenous native microbiota of concern patients, incorporation of catheters provides promising environment for bacterial growth when some volume of urine retained in urethra that is resultant of imperfect drainage from catheter [17]. The complexity associated with CAUTIs commonly reported as orchitis, prostatitis, epididymitis, pyelonephritis, cystitis and meningitis [14]. CAUTI is the most usual type of nosocomial infection globally [17]. According to acute care hospital stats in 2011, UTIs account for more than $12 \%$ of reported infections. CAUTIs are caused by endogenous native microbiota of the patients [18]. Catheters placed inside serves as a conduit for entry of bacteria whereas the imperfect drainage from catheter retains some volume of urine in the bladder providing stability to bacterial residence [17]. CAUTI can develop to complications such as, orchitis, epididymitis and prostatitis in males, and pyelonephritis, cystitis and meningitis in all patients [18].

\section{Surgical Site Infection (SSI)}

The patients with surgery generally account for $2-5 \%$ of surgical site infection (SSI). This is the most common nosocomial infection dominated by Staphylococcus aureus that results in prolonged hospitalization and increased risk of mortality [19]. The origin of SSI pathogens confirmed via endogenous microbiota of the patient also and resultant prevalence of SSI may be as high as $20 \%$ but also remains dependent on procedure and surveillance utilized [20].

\section{Ventilator Associated Pneumonia (VAP)}

Ventilator associated pneumonia (VAP) pronounced as most common healthcare infection especially in intensive care units. The VAP in ventilated patients immediately administered with specific broad-spectrum antibiotics for early control of infection creating the place of resistance easily [21]. The critically ill patients are commonly 
treated with ventilator which increases VAP in them and linked with increased morbidity and mortality that remains associated with $86 \%$ of nosocomial pneumonia [22].

\section{Nosocomial Pathogens}

The range of nosocomial pathogens remains wide yet very well understood and belongs to bacteria, viruses and fungi. The \% prevalence of these microorganisms reported to vary as per patient population, facilities in hospitals, and environment of hospital where care is given.

\section{i. Bacteria}

The most common pathogen responsible for nosocomial infection noted as bacterial species. Even natural flora of the patients becomes pathogenic once the immune system is compromised. The prominently reported genus Acinetobacter is mostly associated with nosocomial infection confined to ICUs. It is present in soil and water and reported to responsible for $80 \%$ of the infections [23].

In addition, patients with organ failure, burn victims and those are in neonatal ward are having common infection with Staphylococcus aureus, S. epidermidis, Escherichia coli and Klebsiella sp. [24]. The patients admitted in ICU and stayed for $>48$ hours or mechanical ventilation, diagnosis of trauma, central venous, pulmonary artery and urinary catheterization reported with bacterial infection of $S$. aureus and Enterobacteriaceae, Pseudomonas aeruginosa and coagulase-negative $S$. aureus [25]. The common spread of bacterial genera recorded with urinary tract infection, pneumonia, primary blood stream, and urinary catheters. Here blood stream infection mainly infected with coagulase-negative Staphylococcus sp. and S. aureus [26].

The spread of bacterial species associated with number of medical devices for example commonly used stethoscope is one of the sources of infection. The presence of coagulase negative Staphylococcus species, Enterococci species, E. coli, Klebsiella species and Acinetobacter species found to be common on stethoscope. The surface and equipment like commodes, bedpans, blood pressure cuffs, washbasins and furniture reported positive with Clostiridium difficile [27]. In addition, presence of extended spectrum beta-lactamases producing Klebsiella and methicillin-resistant $S$. aureus recorded positive in neonatal intensive care unit [28]. The environment of hospital found to be positive with $P$. aeruginosa, vancomycinresistant Enterococci and Acinetobacter baumannii non-fermentative bacteria associated with ventilator-associated pneumonia.

The bacterial species commonly reported with nosocomial infections represented below

The common occurrence of Group A Streptococcus [29, 30]; MRSA [30]; Neisseria meningitis [31, 32]; Borteeeda pertussis [33]; Mycobacterium tuberculosis [34] generally transmitted from patients and staff carriers. The spread of given pathogens occurs via contaminated aerosols those are Pseudomonas sp [35]; A. baumannii [36]; and Legionella sp. [37]. The spread of nosocomial pathogens via ventilation system, fan, air conditions given as Legionella sp. [37]; Clostridia sp. [38, 39] and Nocardia abscesses [40].

\section{ii. Viruses}

Not only the bacteria, but also the viruses are the contributors for nosocomial infection. As per estimation, about $5 \%$ of the nosocomial infections arrives from viruses [41]. The viral route of transmission noted via hand-mouth, faecal-oral and respiratory route [42]. The presence of Hepatitis is common in Health Care Centre and can transmit hepatitis viruses to both patients and workers. In general, transmission of hepatitis B and C occurs via unsafe injection practices [14]. The hospital environment also registered with common presence of influenza, rotavirus, HIV and herpes simplex virus [42]. Since viruses can easily spread through air - number of complications have been reported. The presence of viruses in hospital environment mainly on surfaces and medical equipment responsible for nosocomial infections. The better survival of viruses such as norovirus, influenza virus, and viruses associated with severe acute respiratory syndrome i.e. corona virus also been reported [27]. The presence of respiratory syncytial virus (RSV) in hospital setting recorded by air sampling and also found to be present with children indicated that nosocomial infection by RSV is possible in hospital setting [33]. The spread of adenoviruses able to bring about complications of adenovirus pneumonia and bronchiolitis obliterans once admitted in hospital settings [43, 44]. The children hospitalized with immune compromised conditions reported to get infected by the varicella zoster viruses responsible for chicken pox, singles and symptoms reported to be progressive in other children via airborne route of transmission [45]. As per immunological screening, pregnant women hospitalized in Sudan found to be positive for the maternal cytomegalovirus and rubella infections and can easily transmit to the health planners and care providers via nosocomial infections [46]. 


\section{iii. Fungal Parasites}

The fungal parasites are commonly reported with immunocompromised individuals once comes in contact to the nosocomial infections. The common infection of Aspergillus sp. recorded to occur via environmental contamination. The other fungi such as Candida albicans, Cryptococcus neoformans also reported to be spreading via nosocomial infection [42]. The endogenous microbiota of patients found to be responsible for the spread of Candida infections while Aspergillus infection reported with contaminated air of health care facility [47].

Nosocomial Pathogens and Antibiotic Usage

The indiscriminate use of antibiotics without any regulation and proper screening certainly making many antibiotics non-functional to control their targeted pathogens. The hospital acquired pathogens mainly showcase increased incidences of antibiotic resistance. The present situation can be understood by the many research findings where single use of antibiotics many times proving ineffective resultant making patient suffer for health, wealth and lose its life due to improper treatment.

Among bacterial species Klebsiella sp. and Enterobacter sp. reported to bring about respiratory and non-respiratory infections to about $0 \%$ to $23 \%$ via hospital setting. Further Klebsiella sp. recorded to be intrinsically resistant for penicillin and governs plasmid acquired extended-spectrum beta-lactamases (ESBLs) also. In addition, Enterobacter sp. remains intrinsic resistance towards ampicillin, amoxicillin, amoxicillin-clavalanate, cephalosporins and cefaxitin since they have constituted Amp C beta-lactamase [48]. The antibiotic resistance in Gram-negative bacilli is on rise mainly in those who acts as human pathogens. Acinetobacter sp. termed as typical nosocomial pathogen linked with increased mortality and infection. The species is increasing in resistance towards fluoroquinolone, amikacin, ceftazidime and imipenem. The resistance towards carbapenem brought about by the OXA type carbapenemase production [49].

In a comparative study carried out for nosocomial urinary tract infections versus simple UTIs, important finding recorded with higher antibiotics resistance with nosocomial UTIs. The spread of resistance via nosocomial mode proposed to reduce down once catheters impregnated with antibiotics and recorded as remedy [50]. The nosocomial pathogens as Enterococci species reported to be resistant with all clinically useful antibiotics. The genus acquires this feature via mutation, intrinsic mechanism or by horizontal exchange of genetic element. In terms the most resistance recorded with Entercoccus faecium and E. faecalis [51].

The pathogenicity of $E$. coli has been well documented especially for the extraintestinal E. coli or ExPEC isolate. The ExEPC isolate marked with many virulent factors makes them pathogenic. The ExPEC linked to cause nosocomial infection including urinary tract infections, enteric infections and systemic infections. The ExPEC linked with resistance towards cephalosporins and fluoroquiolones since they are capable of expressing newer -lactamases which is a plasmid mediated AmpC -lactamases, extended spectrum -lactamases and carbapenemases [52].

Similar to the bacteria, fungal nosocomial infection is on rise. As Candida sp. reported just $2 \%$ in 1980 s that goes to $5 \%$ from 1986 to 1989 . In addition, the prevalence of fluconazole-resistant C. krusei and Torulopsis glabrata found to be multidrug resistant and lethal in nature [53].

\section{Reservoirs and transmission}

Microbiota of patient. Bacteria belonging to the endogenous flora of the patient can cause infections if they are transferred to tissue wound or surgical site. Gram-negative bacteria in the digestive tract cause SSI after abdominal surgery [54].

Patient and staff. Transmission of pathogens during the treatment through direct contacts with the patients (hands, saliva, other body fluids etc.) and by the staff through direct contact or other environmental sources (water, food, other body fluids) [54].

Environment. Pathogens living in the healthcare environment i.e. water, food, and equipment can be a source of transmission. Transmission to another patient makes one more reservoir for uninfected patient [42].

Prevention of nosocomial infection. Being a significant cause of illness and death, nosocomial infections need to be prevented from the base line so that their spread can be controlled.

Transmission from environment. Unhygienic environment serves as the best source for the pathogenic organism to prevail. Air, water and food can get contaminated and transmitted to the patients under healthcare delivery. There must be policies to ensure the cleaning and use of cleaning agents on walls, floor, windows, beds, baths, toilets and other medical devices. Proper ventilated and 
fresh filtered air can eliminate airborne bacterial contamination [14]. Regular check of filters and ventilation systems of general wards, operating theatres and ICUs must be maintained and documented. Infections attributed to water are due to failure of healthcare institutions to meet the standard criteria. Microbiological monitoring methods should be used for water analysis. Infected patients must be given separate baths. Improper food handling may cause food borne infections. The area should be cleaned and the quality of food should meet standard criteria [42].

Transmission from staff. Infections can be transferred from healthcare staff. It is the duty of healthcare professionals to take role in infection control. Personal hygiene is necessary for everyone so staff should maintain it. Hand decontamination is required with proper hand disinfectants after being in contact with infected patients [14]. Safe injection practices and sterilized equipment should be used. Use of masks, gloves, head covers or a proper uniform is essential for healthcare delivery [42].

Hospital waste management. Waste from hospitals can act as a potential reservoir for pathogens that needs proper handling. 10-25\% of the waste generated by healthcare facility is termed as hazardous. Infectious healthcare waste should be stored in the area with restricted approach [14]. Waste containing high content of heavy metals and waste from surgeries, infected individuals, contaminated with blood and sputum and that of diagnostic laboratories must be disposed off separately. Healthcare staff and cleaners should be informed about hazards of the waste and its proper management [42].

Conclusions. Infections associated with healthcare are no longer limited to hospitals and clinics. Infections spread easily through all healthcare facilities, exposing patients, healthcare staff, and the general public to pathogens that are becoming more virulent and resistant. There are currently a number of strategies available to mitigate these risks, however, the introduction or use of these interventions is contingent on all stakeholders being educated on their benefits.

\section{ОГЛЯД ВНУТРІШНЬОЛІКАРНЯНИХ ІНФЕКЦИЙ: ДЖЕРЕЛО ТА ПРОФІЛАКТИКА}

\author{
Д.Б. Фуле, А.В. Манвар
}

Кафедра мікробіології, Коледж мистеитв, торгівлі, науки і технологій ім. Днянопасака, Парбхані (Індія)

Резюме

Внутрішньолікарняні інфекції викликають серйозне занепокоєння в галузі охорони здоров'я в усьому світі, особливо в країнах, що розвиваються, де боротьба з інфекцією ускладнена через фінансові обмеження. Незважаючи на значний спад інфекційних захворювань внаслідок розвитку медицини та медичних технологій, загальновизнано, що внутрішньолікарняні інфекції є однією 3 ключових перешкод для покращення ефективності лікування. Поширення збудників пов'язано зі збільшенням в лікарнях кількості виробів багаторазового використання, наприклад, одним із головних джерел зараження є стетоскоп. На стетоскопі виявлені коагулазонегативні види Staphylococcus, види Enterococci, Escherichia coli, Klebsiella та Acinetobacter. Безконтрольне вживання антибіотиків без будь-якого регулювання та належного скринінгу, безумовно, призводить до виникнення резистентних штамів. Виділені з лікарень збудники внутрішньолікарняних інфекцій в цілому демонструють збільшення випадків підвищеної стійкості до антибіотиків. Мета цього дослідження - вивчити епідеміологічні характеристики внутрішньолікарняних інфекцій та виявити ефективні заходи щодо їх запобігання.

Ключові слова: внутрішньолікарняні інфекції, мікробні збудники, профілактика та передача. 
1. Fehr J, Hatz C, Soka I, Kibatala P, Urassa H, Smith T, Mshinda H, Frei R, Widmer A. Risk factors for surgical site infection in a Tanzanian district hospital: a challenge for the traditional national nosocomial infections surveillance system index. Infect Control Hosp Epidemiol. 2006; 27(12):1401-1404.

2. Khan HA, Baig FK, Mehboob R. Nosocomial infections: Epidemiology, prevention, control and surveillance. Asian Pacific Journal of Tropical Biomedicine. 2017; 7(5):478-482.

3. Vincent JL, Rello J, Marshall J, Silva E, Anzueto A, Martin CD, Reinhart K. International study of the prevalence and outcomes of infection in intensive care units. Jama. 2009; 302(21):2323 2329.

4. Mawalla B, Mshana SE, Chalya PL, Imirzalioglu C, Mahalu W. Predictors of surgical site infections among patients undergoing major surgery at Bugando Medical Centre in Northwestern Tanzania. BMC Surg. 2011; 11:10-21.

5. Allegranzi B, Nejad SB, Castillejos GG, Kilpatrick C, Kelley E. Report on the Burden of Endemic Health Care-Associated Infection Worldwide. Geneva, Switzerland: World Health Organization. Lancet Infect Dis. 2011; 13:84351 .

6. Gupta A, Divya CV, Singh DK, Krutarth B, Maria N, Srinivas R. Prevalence of health care associated infections in a tertiary care hospital in Dakshina Kannada, Karnataka: a hospital based cross sectional study. International Journal of Medical Research and Health Sciences. 2015; $4(2): 317-321$.

7. Hughes Ronda G, editor. Patient Safety and Quality: An Evidence-Based Handbook for Nurses. Agency for Healthcare Research and Quality (US), April, 2008.

8. Revelas A. Healthcare-associated infections: A public health problem. Nigerian medical journal: journal of the Nigeria Medical Association. 2012; 53(2):59.

9. Haque M, Sartelli M, McKimm J, Bakar MA. Health care-associated infections-an overview. Infection and drug resistance. 2018; $11: 2321$
10. Klevens RM, Edwards JR, Richards Jr CL, Horan TC, Gaynes RP, Pollock DA, Cardo DM. Estimating health care-associated infections and deaths in US hospitals. 2002. Public health reports. 2007; 122(2):160-166.

11. Centers for Disease Control and Prevention. (2011). Vital signs: central line-associated blood stream infections-United States, 2001, 2008, 2009. Annals of emergency medicine. 58(5):447450 .

12. World Health Organization. Preventing bloodstream infections from central line venous catheters. URL: http:/www.who.int/patient safety/ implementation/ bsi /en /index. html. 2012.

13. Haddadin Y, Annamaraju P, Regunath H. Cent ral line associated blood stream infections (CLABSI). StatPearls; 2020.

14. CDC Types of healthcare-associated infections. Healthcare-associated infections (HAIs). 2016. [Online] Available from:https://www.cdc.gov/ HAI/infectionTypes.html

15. World Health Organization. Preventing bloodstream infections from central line venous catheters. WHO World Health Organisation, Geneva, Switzerland; 2014.

16. Lin $\mathrm{KY}$, Cheng A, Chang $\mathrm{YC}$, Hung $\mathrm{MC}$, Wang JT, Sheng WH, Chang SC. Central lineassociated bloodstream infections among critically-ill patients in the era of bundle care. Journal of microbiology, immunology and infection. 2017; 50(3):339-348.

17. Warren JW. Catheter-associated urinary tract infections. International journal of antimicrobial agents. 2001; 17(4):299-303.

18. CDC. Bloodstream infection event (central line-associated bloodstream infection and non-central line-associated bloodstream infection). Atlanta, Georgia: CDC; 2015.

19. Anderson DJ. Surgical site infections. Infectious disease clinics of North America. 2011; 25(1):135-153.

20. Owens CD, Stoessel K. Surgical site infections: epidemiology, microbiology and prevention. Journal of hospital infection. 2008; 70:310 .

21. Hunter JD. Ventilator associated pneumonia. BMJ. 2012; 344:3325. 
22. Koenig SM, Truwit JD. Ventilator-associated pneumonia: diagnosis, treatment, and prevention. Clin Microbiol Rev. 2006; 19(4):637-657.

23. Joshi SG, Litake GM. Acinetobacter baumannii: An emerging pathogenic threat to public health. World Journal of Clinical Infectious Diseases. 2013; 3(3):25-36.

24. Salamati P, Rahbarimanesh AA, Yunesian M, Naseri M. Neonatal nosocomial infections in Bahrami children hospital. The Indian Journal of Pediatrics. 2006; 73(3):197-200.

25. Ki V, Rotstein C. Bacterial skin and soft tissue infections in adults: a review of their epidemiology, pathogenesis, diagnosis, treatment and site of care. Canadian Journal of Infectious Diseases and Medical Microbiology. 2008; 19(2):173184.

26. Richards MJ, Edwards JR, Culver DH, Gaynes RP. Nosocomial infections in medical intensive care units in the United States. Critical care medicine. 1999; 27(5):887-892.

27. Weinstein RA, Hota B. Contamination, disinfection, and cross-colonization: are hospital surfaces reservoirs for nosocomial infection? Clinical infectious diseases. 2004; 39(8):1182-1189.

28. Sengupta S, Sirkar A, Shivananda PG. Stethoscopes and nosocomial infection. The Indian Journal of Pediatrics. 2000; 67(3):197.

29. O’Brien KL, Beall B, Barrett NL, Cieslak PR, Reingold A, Farley MM, et al. Epidemiology of invasive group A streptococcus disease in the United States, 1995-1999. Clinical Infectious Diseases. 2002; 35(3):268-276.

30. Rodvold KA, McConeghy KW. Methicillin-resistant Staphylococcus aureus therapy: past, present, and future. Clinical infectious diseases. 2014; 58(suppl 1):20-27.

31. Castelblanco RL, Lee M, Hasbun R. Epidemiology of bacterial meningitis in the USA from 1997 to 2010: a population-based observational study. The Lancet Infectious diseases. 2014; 14(9):813-819.

32. Pizza M, Rappuoli R. Neisseria meningitidis: pathogenesis and immunity. Current opinion in microbiology. 2015; 23:68-72.

33. Aintablian N, Walpita P, Sawyer MH. Detection of Bordetella pertussis and respiratory syncytial virus in air samples from hospital rooms. Infection Control and Hospital Epidemiology. 1998; 19(12):918-923.

34. Pearson ML, Jereb JA, Frieden TR, Craw-ford JT, Davis BJ, Dooley SW, Jarvis WR. Nosocomial transmission of multidrug-resistant Mycobacterium tuberculosis: a risk to patients and health care workers. Annals of internal medicine. 1992; 117(3):191-196.

35. Micek ST, Wunderink RG, Kollef MH, Chen C, Rello J, Chastre J, Calbo E. An international multicenter retrospective study of Pseudomonas aeruginosa nosocomial pneumonia: impact of multidrug resistance. Critical Care. 2015; 19(1):219.

36. Richards AM, Abu Kwaik Y, Lamont RJ. Code blue: Acinetobacter baumannii, a nosocomial pathogen with a role in the oral cavity. Molecular oral microbiology. 2015; 30(1):2-15.

37. Cunha BA, Burillo A, Bouza E. Legionnaires' disease. The Lancet. 2016; 387(10016):376-385.

38. Goldstein EJ, Johnson S, Maziade PJ, McFarland LV, Trick W, Dresser L, Low DE. Pathway to prevention of nosocomial Clostridium difficile infection. Clinical Infectious Diseases. 2015; 60(suppl_2):148-158.

39. Leffler DA, Lamont JT. Clostridium difficile infection. New England Journal of Medicine. 2015; 372(16):1539-1548.

40. Bagaitkar J, Demuth DR, Scott DA. Tobacco use increases susceptibility to bacterial infection. Tobacco induced diseases. 2008; 4(1):12.

41. Aitken C, Jeffries DJ. Nosocomial spread of viral disease. Clinical microbiology reviews. 2001; 14(3):528-546.

42. Ducel G, Fabry J, Nicolle L. Prevention of hospital acquired infections: a practical guide. Prevention of hospital acquired infections: a practical guide. 2002.

43. Castro-Rodriguez JA, Daszenies C, Garcia M, Meyer R, Gonzales R. Adenovirus pneumonia in infants and factors for developing bronchiolitis obliterans: a 5-year follow-up. Pediatric pulmonology. 2006; 41(10):947-953.

44. Carducci A, Verani M, Lombardi R, Casini B, Privitera G. Environmental survey to assess viral contamination of air and surfaces in hospi- 
tal settings. Journal of Hospital Infection. 2011; 77(3):242-247.

45. Schaffner W. An outbreak of airborne nosocomial varicella. Pediatrics. 1982; 70:550-556.

46. Hamdan HZ, Abdelbagi IE, Nasser NM, Adam I. Seroprevalence of cytomegalovirus and rubella among pregnant women in western Sudan. Virology Journal. 2011; 8(1):217.

47. Sydnor ER, Perl TM. Hospital epidemiology and infection control in acute-care settings. Clinical microbiology reviews. 2011; 24(1):141-173.

48. Bouza E, Cercenado E. Klebsiella and enterobacter: antibiotic resistance and treatment implications. In Seminars in respiratory infections. 2002; 17(3):215-230.

49. Lee K, Yong D, Jeong SH, Chong Y. Multidrug-resistant Acinetobacter spp.: increasingly problematic nosocomial pathogens. Yonsei med- ical journal. 2011; 52(6):879-891.

50. Kalsi J, Arya M, Wilson P, Mundy A. Hospital-acquired urinary tract infection. International journal of clinical practice. 2003; 57(5):388-391.

51. Hollenbeck BL, Rice LB. Intrinsic and acquired resistance mechanisms in enterococcus. Virulence. 2012; 3(5):421-569.

52. Pitout J. Extraintestinal pathogenic Escherichia coli: a combination of virulence with antibiotic resistance. Frontiers in microbiology. 2012; 3:9.

53. Fridkin SK, Jarvis WR. Epidemiology of nosocomial fungal infections. Clinical microbiology reviews. 1996; 9(4):499-511.

54. Khan HA, Baig FK, Mehboob R. Nosocomial infections: Epidemiology, prevention, control and surveillance. Asian Pacific Journal of Tropical Biomedicine. 2017; 7(5):478-482.

Received 11.03.2021 